\title{
Hygroscopic contributions to bark water storage and controls exerted by internal bark structure over water vapor absorption
}

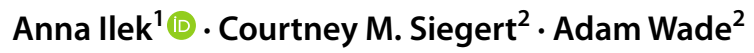

Received: 9 September 2020 / Accepted: 6 January 2021 / Published online: 24 January 2021

(c) The Author(s) 2021

\begin{abstract}
Key message Hygroscopicity is a crucial element of bark water storage and can reach $>60 \%$ of water holding capacity of bark depending on tree species

Abstract Bark forms the outer layer of woody plants, and it is directly exposed to wetting during rainfall and reacts to changes in relative humidity, i.e., it may exchange water with the atmosphere through absorption and desorption of water vapor. A current paradigm of bark hydrology suggests that the maximum water storage of bark empties between precipitation events and is principally controlled by bark thickness and roughness. We hypothesize that (1) the ability of bark to absorb water vapor during non-rainfall periods (i.e., hygroscopicity) leads to partial saturation of bark tissues during dry periods that may alter the rate of bark saturation during rainfall, and (2) the degree of bark saturation through hygroscopic water is a function of internal bark structure, including porosity and density, that varies among species. To address these questions, we conducted laboratory experiments to measure interspecific differences in bark physical structure as it relates to water storage mechanisms among common tree species (hickory (Carya spp.), oak (Quercus spp.), sweetgum (Liquidambar styraciflua), and loblolly pine (Pinus taeda)) in the southeastern United States. Furthermore, we considered how these properties changed across total bark, outer bark, and inner bark. We found a distinct difference between hickory and oak, whereby hickory had $5.6 \%$ lower specific density, $31.1 \%$ higher bulk density, and $22.4 \%$ lower total porosity of outer bark resulting in higher hygroscopicity compared to oaks. For all species, hygroscopicity increased linearly with bulk density $\left(R^{2}=0.65-0.81\right)$ and decreased linearly with total porosity $\left(R^{2}=0.64-0.88\right)$. Overall, bark hygroscopicity may constitute an average of $30 \%$ of total bark water storage capacity. Therefore, in humid climates like those of the southeastern USA, the proportion of bark that remains saturated during non-storm conditions should not be considered negligible.
\end{abstract}

Keywords Forest hydrology $\cdot$ Bark hygroscopicity $\cdot$ Outer bark $\cdot$ Total bark $\cdot$ Physical properties of bark

\section{Introduction}

Bark constitutes the outermost layer of stems, branches, and roots of trees and shrubs, and plays very different functions during the life cycle of woody plants. It separates underlying living tissues from the atmosphere and in case of the bark

Communicated by A. Franco.

Anna Ilek

anna.ilek@up.poznan.pl

1 Faculty of Forestry and Wood Technology, Department of Forest Sites and Ecology, Poznań University of Life Sciences, Poznan, Poland

2 Department of Forestry, Forest and Wildlife Research Center, Mississippi State University, Starkville, USA of roots-from the soil matrix. Bark constitutes a defensive barrier against pests, pathogens, and herbivores (Biggs 1992; Dossa et al. 2018). Bark also creates habitat for many organisms, such as mosses, lichens or arthropods, and bark properties like the texture, structure, $\mathrm{pH}$ or thickness often determine the abundance and diversity of those organisms (Nicolai 1986; Everhart et al. 2009). Many studies emphasize the role of bark properties in the protection of trees during fire events (Pinard and Huffman 1997; Bauer et al. 2010; Staver et al. 2020). Apart from the physical protection of trees, bark also has important physiological functions, like wound repair, photosynthesis, and storage of organic compounds (Dossa et al. 2018). Since bark can absorb water from the air and store liquid water from rainfall, stemflow, dew, and fog, bark helps to protect trees from desiccation as well (Romero 2014). 
Bark can be divided into the dead, outer bark and the living, inner bark, which includes the secondary phloem, the cortex, and the phelloderm, which is also called 'active bark' (Feng et al. 2013; Rosell 2019). Anatomists often refer to the inner bark as 'phloem' and the outer bark as 'rhytidome' (Martin and Crist 2007). Outer and inner bark differ significantly from each other, and from wood (i.e., sapwood, heartwood) in terms of chemical composition, physical properties, and anatomy, and morphological characteristics (Pausas 2015). While inner bark contains physiologically active tissues, and among others stores water and other compounds, translocates photosynthates, and is a capacitor of radial transfer of water from phloem into the xylem, the outer bark is a layer of dead tissue and is primarily responsible for reducing water loss, providing mechanical stability, and protecting against stressful climate conditions and fire (Martin and Crist 2007; Pausas 2015; Pfautsch et al. 2015; Rosell et al. 2017).

The proportion between outer and inner bark may depend on the location along the tree trunk and tree age (Krogell et al. 2012). For example, in longleaf pine (Pinus palustris Mill.), the outer bark thickness decreased with height up the tree trunk while inner bark thickness was essentially constant along the tree trunk, and thus the proportion between outer and inner bark decreased from stump height to the top of tree (Eberhardt 2012). In turn in pitch pine (Pinus rigida Mill.), the share of outer bark to total bark increased from $27 \%$ at 5 years old to $91 \%$ at 50 years, while in sugar maple (Acer saccharum Marsch.), the share of outer bark increased from $50 \%$ at 60 years to $67 \%$ at an age close to 140 years old (Spalt and Reifsnyder 1962). Analyzing the bark of 640 tree species Rosell (2016) found that the inner bark tended to be thicker in locations with higher mean temperature and with less rainfall. Moreover, Rosell (2016) also stated that stem diameter explained 72,68 and $27 \%$ of the variation in total, inner, and outer bark thickness, respectively.

The range of physical bark characteristics discussed above acts in combination with rainfall characteristics to influence the fate in incident precipitation moving through the forest canopy (André et al. 2008; Germer et al. 2010; Van Stan and Levia 2010; Siegert and Levia 2014). Whether rainwater is absorbed into bark tissue or diverted to stemflow and throughfall is a function of how much water the bark can store (i.e., bark water storage capacity). Depending on forest type and climate, interception loss ranges from 10 to 50\% (e.g., Llorens et al. 1997; Bryant et al. 2005; Roth et al. 2007; Carlyle-Moses and Gash 2011), wherein bark may even intercept more water than leaves (Liu 1998; Llorens and Gallart 2000). Herwitz (1985) found that in tropical rainforests, bark interception can constitute more than $50 \%$ of total rainfall interception under still-air conditions, whereas under turbulent conditions, bark interception can constitute up to $80 \%$ of intercepted rainwater. Thus knowledge of bark water absorption properties is of importance in determining hydrologic inputs in forested watersheds.

Since bark forms the outer layer of trees, it is directly exposed not only to wetting during rainfall but also to atmospheric water vapor during non-rainfall and reacts to the changes in relative humidity and may exchange water with the atmosphere through both absorption and desorption. This process describes bark hygroscopicity, which often leads to temporary changes in bark thickness (Gall et al. 2002; Oberhuber et al. 2020). Limited research has been conducted on bark hygroscopicity and the majority of which does not distinguish between outer and inner bark (Reifsnyder et al. 1967). Herzog et al. (1995) suggested the hygroscopicity is limited only to the outer bark. According to Gall et al. (2002), the inner bark may also react to the changes in relative humidity.

Ilek et al. (2017a) found that bark hygroscopicity may represent 10 to $30 \%$ of the maximum water storage capacity of bark, depending on tree species. However, our relatively weak understanding of the hygroscopicity properties of bark limits the broader assessment of the importance of bark hygroscopicity in the water balance of forest ecosystems and the influence of bark on the microclimate regulation inside the forest. Especially in humid climates, like those found in the southeastern USA, the role of bark hygroscopicity may be underestimated in its contribution to the hydrologic cycle due to continuous exposure of bark to abundant sources of atmospheric vapor during rain-free periods. Therefore, the objectives of our research are: (1) to quantify the proportion total bark hygroscopicity that is represented by the outer and inner bark, (2) to determine the physical properties of outer and total bark and relate these properties to bark hygroscopicity, and 3) to quantify the proportion of bark hygroscopicity to total water holding capacity of outer and total bark among common species in the southeastern United States. We hypothesize that (1) the ability of bark to absorb water vapor during nonrainfall periods (i.e., hygroscopicity) leads to partial saturation of bark tissues during dry periods that may alter the rate of bark saturation during rainfall, (2) the degree of bark saturation through hygroscopic water is a function of internal bark structure, including porosity and density, that varies among species, and 3) bark hygroscopicity represents a non-negligible proportion of bark water storage capacity in the species of study. To address these hypotheses, we collected bark samples from six tree species common throughout southeastern USA forests and conducted laboratory experiments to assess bark hygroscopicity as it relates to species-specific tree traits. 


\section{Materials and methods}

\section{Study area}

Bark samples were collected from an upland, mixed-hardwood forest located in a 15 ha experimental forest $\left(33.4245^{\circ}\right.$, $-88.7607^{\circ}$ ) near Starkville, Mississippi, United States. The stand basal area was $33.6 \mathrm{~m}^{2} \mathrm{ha}^{-1}$ with a density of 207 trees $\mathrm{ha}^{-1}$. Dominant canopy trees at the site include white oak (Quercus alba L.), post oak (Q. stellata Wangenh.), cherrybark oak (Q. pagoda Raf.), Shumard oak (Q. shumardii Buckland), shagbark hickory (Carya ovata (Mill.) K. Koch), and pignut hickory (C. glabra Miller) (Limpert and Siegert 2019), all of which are deciduous temperate species commonly found in the eastern United States. At the property boundary, the stand transitions into a mixed stand, with loblolly pine (Pinus taeda L.) becoming more prevalent. Leaf area index (LAI) of the stand was estimated to be $4.16 \mathrm{~m}^{2} \mathrm{~m}^{-2}$ from litter trap collections during the leaf fall periods of 2014 and 2015. Leaf emergence typically begins in mid-March and leaf senescence and leaf fall typically begins in late October. The area is characterized as humid subtropical and receives approximately $140 \mathrm{~cm}$ of annual rainfall, distributed evenly throughout the year (Arguez et al. 2010). Average summer temperature ranges from 23.5 to $27.7^{\circ} \mathrm{C}$ while average winter temperature ranges from 6.6 to $14.4^{\circ} \mathrm{C}$ (Arguez et al. 2010).

\section{Bark samples collection}

Bark samples were collected in September 2019 from the stems of 48 living trees, which represent five broadleaved and one coniferous forest tree species: pignut hickory (Carya glabra Mill.), mockernut hickory (Carya tomentosa (Lam.) Nutt.), post oak (Quercus stellata Wangenh.), white oak (Quercus alba L.), sweetgum (Liquidambar styraciflua L.) and loblolly pine (Pinus taeda L.). For each tree species, we selected eight individual trees with a diameter at breast height ranging from 30 to $45 \mathrm{~cm}$. Three bark samples, approximately $100 \mathrm{~cm}^{2}$ were extracted from each tree stem at the breast height using a hand saw, chisels, and hammer. Bark samples were removed down to the vascular cambium. Taking into account that mosses and lichens may affect the bark water storage capacity (Van Stan et al. 2015; Hargis et al. 2019) and bark hygroscopicity, only bark without visible mosses and lichens present was collected.

\section{Laboratory experiments}

All bark samples collected from the stems of living trees were first dried at $35{ }^{\circ} \mathrm{C}$ to constant mass, and after this, were measured for thickness of total bark, outer bark, and inner bark using a caliper. Initial bark drying was done to prevent variability in bark water content and subsequent swelling between the outer and inner bark during measurements (Eberhardt 2012, 2015) and between particular tree species as well. Based on these measurements, we calculated the outer bark to total bark thickness ratio. Next, each bark sample was divided into segments $\left(\sim 6-8 \mathrm{~cm}^{2}\right)$ using a band saw, and these segments were used to analyze specific and bulk densities, total porosity, bark hygroscopicity, and bark water storage capacity. We determined these properties for both outer and total bark, excepting loblolly pine for which only properties of the total bark were measured, due to relatively small share of the inner bark $(\sim 11 \%)$ in its total ovendry bark mass (Schultz 1997).

Bulk density was measured in three replicates for outer bark and three replicates for total bark of each tree. First, bark samples were placed in water for 5 days (Ilek et al. 2017a), and then the volume of each outer and total bark sample was measured by the water displacement method in a graduated cylinder. Bulk density was calculated as the ratio of dry mass of bark to its volume, wherein the dry mass was determined after drying bark samples at $105^{\circ} \mathrm{C}$.

Specific density was determined by the pycnometer method using the $99.8 \%$ ethyl alcohol (Ilek et al. 2017a). Multiple bark samples from each individual tree were first ground and then aggregated into one outer bark sample and into one total bark sample for each tree. After homogenizing the ground bark, specific density was determined on a 2-g subsample for each tree. Based on specific density SD $\left(\mathrm{g} \mathrm{cm}^{3}\right)$ and bulk density BD $\left(\mathrm{g} \mathrm{cm}^{3}\right)$, the total porosity TP $\left(\mathrm{cm}^{3} \mathrm{~cm}^{-3}\right)$ of the outer and total bark was calculated following the equation:

$T P=\frac{S D-B D}{S D}$

To assess how the internal structure of outer and total bark affected hygroscopic properties, we measured two kinds of bark hygroscopicity: actual and potential. Ilek et al. (2017a) defined the actual hygroscopicity of bark as the maximum amount of water that can be absorbed by the bark with given physical properties from saturated air (i.e., relative humidity is $100 \%$ ), assuming that water is absorbed only by the outer bark layer, which is directly exposed to atmospheric conditions. In turn, we understand the potential hygroscopicity as the maximum amount of water that can be absorbed from saturated air by the bark in the absence of structure (i.e., ground bark). We measured actual hygroscopicity of outer and total bark samples in desiccators filled with water, where relative humidity was maintained at $100 \%$. To ensure the absorption of water only through the external layer of bark samples, we first secured internal and side surfaces of outer and total bark 
samples with silicone; details of bark samples preparation were described by Ilek et al. (2017a). The mass of each sample in the desiccator was measured every 2 days until a constant mass was achieved, indicating that the samples with intact internal structure had reached its maximum absorption capacity, i.e., actual hygroscopicity. Time of achievement of actual hygroscopicity, or the amount of time it took for samples to reach actual hygroscopicity, was also recorded for each outer and total bark sample. The actual hygroscopicity $S_{H A}$ of a particular bark sample ( $\mathrm{mm}$ of water in an outer or total bark layer with a thickness of $1 \mathrm{~cm}$ ) was calculated according to the formula:

$S_{\mathrm{HA}}=\frac{M_{\mathrm{H}_{2} \mathrm{O}}}{V} \cdot 10$

where $M_{\mathrm{H} 2 \mathrm{O}}$ is the mass of water which has been absorbed by outer or total bark sample (g), which equals water volume with assuming its density $1 \mathrm{~g} \cdot \mathrm{cm}^{3}, V$ is the volume of a sample calculated as the ratio of the dry mass of the bark with an intact internal structure to the bulk density of outer or total bark $\left(\mathrm{cm}^{3}\right), 10$ is a factor of conversion into $\mathrm{mm}$ of $\mathrm{H}_{2} \mathrm{O}$ in an outer or total bark with a thickness of $1 \mathrm{~cm}$.

Based on measurements of actual hygroscopicity of outer and total bark, we calculated:

(1) Actual hygroscopicity of inner bark $S_{\mathrm{HA}, I}(\mathrm{~mm}$ of water in an inner bark layer with a thickness of $1 \mathrm{~cm}$ ) according to the equation:

$S_{\mathrm{HA}, I}=\frac{S_{\mathrm{HA}, T} \cdot T-S_{\mathrm{HA}, O} \cdot O}{I}$

where $S_{\mathrm{HA}, T}$ is the actual hygroscopicity of total bark ( $\mathrm{mm}$ of water in a total bark layer with a thickness of $1 \mathrm{~cm}), S_{\mathrm{HA}, O}$ is the actual hygroscopicity of outer bark $(\mathrm{mm}$ of water in an outer bark layer with a thickness of $1 \mathrm{~cm}), T, O$ and $I$ is the thickness of total, outer and inner bark, respectively $(\mathrm{cm})$.

(2) Contribution of the outer bark $\mathrm{CO}(\%)$ to actual hygroscopicity of total bark according to the equation:

$\mathrm{CO}=\left(\frac{S_{\mathrm{HA}, O} \cdot O}{S_{\mathrm{HA}, T} \cdot T}\right) \cdot 100$

To measure the potential hygroscopicity of bark, we destroyed the internal bark structure by grinding in a laboratory mill. The potential hygroscopicity was determined with an assumption that $1 \mathrm{~cm}^{3}$ of each ground sample contains the same mass and bark particles with the same size. Thus, bark samples were ground to pass through a $0.25 \mathrm{~mm}$ sieve, and placed in a ceramic crucible. Next, each crucible was gently tapped in the same way to remove any large air pockets. We prepared two ground bark samples for each broadleaved tree: with outer bark only, and with total bark (outer and inner bark). In the case of loblolly pine, only total bark was ground. Then samples were placed in the desiccators where relative humidity was $100 \%$. Ground bark samples were weighed every 2 days, and after reaching a stable saturated mass, bark samples were dried at $105^{\circ} \mathrm{C}$. The potential hygroscopicity $S_{\mathrm{HP}}$ of a particular bark sample ( $\mathrm{mm}$ of water in an outer or total bark layer with a thickness of $1 \mathrm{~cm}$ ) was calculated according to the formula:

$S_{\mathrm{HP}}=\frac{M_{\mathrm{H}_{2} \mathrm{O}}}{M_{\mathrm{S}} / \mathrm{BD}} \cdot 10$

where $M_{\mathrm{H} 2 \mathrm{O}}$ is the mass of water which has been absorbed by ground sample of outer or total bark $(\mathrm{g}), M_{\mathrm{S}}$ is the dry mass of ground bark sample (g), BD is the bulk density of outer or total bark with intact structure $\left(\mathrm{g} \mathrm{cm}^{-3}\right), 10$ is a factor of conversion into $\mathrm{mm}$ of $\mathrm{H}_{2} \mathrm{O}$ in an outer or total bark with a thickness of $1 \mathrm{~cm}$.

To compare actual and potential hygroscopicity of bark, we also considered percent bark moisture content, which was calculated as the ratio of water absorbed by bark to its dry mass.

We determined the water storage capacity of outer and total bark after actual hygroscopicity measurements. After mass stabilization of bark samples in desiccators, we immersed bark samples in water for seven days. Then, the bark samples were weighed, dried at $105{ }^{\circ} \mathrm{C}$ for $24 \mathrm{~h}$, and weighed again. Based on these masses, we calculated the bark water storage capacity of outer and total bark in a way analogous to the Eq. 2.

\section{Statistical analysis}

The statistical analysis and associated graphics were performed in Statistica 13.3 PL (StatSoft Inc.). Significant differences in outer bark thickness, outer to total bark thickness ratio, bulk density of total bark, total porosity of outer and total bark, total bark water storage capacity, actual hygroscopicity of outer and total bark ( $\mathrm{mm}$ and \%), potential hygroscopicity of outer $(\mathrm{mm})$ and total bark (\%) between particular tree species were tested by one-way ANOVA and post-hoc Tukey's test after previous checking of normality by the Shapiro-Wilk test and the equality of variance by the Levene's test. In the case of the non-parametric nature of data, a Kruskal-Wallis test and post-hoc Dunn's test were used to compare total bark thickness, specific density of outer and total bark, bulk density of outer bark, time of achievement the actual hygroscopicity by outer and total bark, potential hygroscopicity of total $(\mathrm{mm})$ and outer bark (\%), actual hygroscopicity of inner bark, outer bark water storage capacity, contribution of the outer bark 
in the hygroscopicity of total bark, and contribution of the actual hygroscopicity in the outer and total bark water storage capacity between tree species. To test for differences of specific density, bulk density, total porosity, water storage capacity, actual hygroscopicity, and potential hygroscopicity between outer bark and total bark within each tree species we used $t$-tests. All tests were performed at a significance level of 0.05 .

\section{Results}

\section{Bark hygroscopicity}

Time of achievement of actual hygroscopicity ranged from 7 to 20 days for outer bark (mean $=14$ days) and from 9 to 42 days for total bark (mean $=20$ days). It took 2.3 times longer (17 days) for total bark of hickories to reach a steady state of actual hygroscopicity compared to sweetgum $(p<0.001)$ (Table 1).

Actual hygroscopicity of outer bark ranged from 0.90 to $2.28 \mathrm{~mm}$ of water in a standardized outer bark thickness of $1 \mathrm{~cm}$, while actual hygroscopicity of total bark ranged from 0.55 to $1.99 \mathrm{~mm}$ in a standardized total bark thickness of $1 \mathrm{~cm}$. Hickory species had the highest mean values of actual hygroscopicity in both outer bark and total bark (Fig. 1a). These values were 32.3 and $30.8 \%$ higher than other species, with the largest difference observed between total bark hygroscopicity of hickory species and loblolly pine. However, within genera (i.e., Carya, Quercus) there were not differences in actual hygroscopicity. Actual hygroscopicity of inner bark derived from Eq. 3 was not significantly different among species $(p=0.552)$ (Table 1).

Overall, potential hygroscopicity was higher in outer bark compared to total bark (1.75 vs. $1.48 \mathrm{~mm}, p=0.004)$. Hickory species had higher potential hygroscopicity values in outer bark and total bark compared to the other species (Fig. 1a). Potential hygroscopicity was greater than actual hygroscopicity in outer bark among hickories and sweetgum $(p<0.001)$ and in total bark for pignut hickory $(p=0.021)$ and loblolly pine $(p<0.001)$.

Actual and potential hygroscopicity as a percentage of dry mass was on average $24.9 \pm 0.4 \%$ of outer bark and $24.3 \pm 0.6 \%$ of total bark, with no differences among species (Fig. 1b). However, there were differences between types of hygroscopicity within a species. Sweetgum and hickory species had 15.1-21.1\% higher potential hygroscopicity compared to actual hygroscopicity in outer bark. For total bark, white oak and loblolly pine had 11.4 and $27.3 \%$ higher potential hygroscopicity compared to actual hygroscopicity.

The contribution of the outer bark in the actual hygroscopicity of total bark averaged $59.8 \pm 2.5 \%$ with no statistical differences among species (data not shown).

\section{Physical bark properties}

Thickness of the outer bark ranged from 0.25 to $1.36 \mathrm{~cm}$, while the thickness of total bark ranged from 0.51 to $2.22 \mathrm{~cm}$. Among all tree species, sweetgum had the thinnest total bark, while mockernut hickory, pignut hickory, and loblolly pine had the thickest bark (Table 2). The ratio of outer bark to total bark thickness for hickories was less than 0.50 , and for oaks and sweetgum was more than 0.50 (Table 2).

Specific density of outer bark ranged from 1.601 to $1.736 \mathrm{~g} \mathrm{~cm}^{-3}$, and specific density of total bark ranged from 1.577 to $1.716 \mathrm{~g} \mathrm{~cm}^{-3}$ (Fig. 2a). Overall, the specific density of outer bark was $5.1 \%$ greater in oaks than hickories. For total bark, only white oak specific density was much lower and similar to hickories. In hickories and sweetgum, the specific density of total bark was, on average, $1.7 \%$ greater than the specific density of outer bark, while the opposite trend was observed in oak (average decrease of 3.6\%). The specific density of pine bark was intermediate in magnitude compared to broadleaved species.

Bulk density of outer bark ranged from 0.321 to $0.870 \mathrm{~g} \mathrm{~cm}^{-3}$, while bulk density of total bark ranged from 0.201 to $0.706 \mathrm{~g} \mathrm{~cm}^{-3}$ (Fig. 2b). Outer bark of hickories had
Table 1 Time of achievement the actual hygroscopicity by outer and total bark (days) and actual hygroscopicity of inner bark of broadleaved tree species ( $\mathrm{mm}$ of water in a layer of inner with a thickness of $1 \mathrm{~cm}$ )

\begin{tabular}{|c|c|c|c|c|c|c|}
\hline \multirow[t]{3}{*}{ Species } & \multicolumn{4}{|c|}{ Time of achievement the actual hygroscopicity } & \multirow{2}{*}{\multicolumn{2}{|c|}{$\begin{array}{l}\text { Actual hygroscopicity of } \\
\text { inner bark }\end{array}$}} \\
\hline & \multicolumn{2}{|l|}{ Outer bark } & \multicolumn{2}{|l|}{ Total bark } & & \\
\hline & Mean \pm Std error & Median & Mean \pm Std error & Median & Mean \pm Std error & Median \\
\hline Mockernut hickory & $16 \pm 1$ & $17^{\mathrm{a}}$ & $31 \pm 3$ & $34^{\mathrm{a}}$ & $1.28 \pm 0.14$ & $1.19^{\mathrm{a}}$ \\
\hline Pignut hickory & $16 \pm 1$ & $19^{\mathrm{a}}$ & $29 \pm 3$ & $26^{\mathrm{a}}$ & $1.65 \pm 0.12$ & $1.60^{\mathrm{a}}$ \\
\hline Post oak & $14 \pm 1$ & $12^{\mathrm{a}}$ & $17 \pm 1$ & $16^{\mathrm{ab}}$ & $1.33 \pm 0.13$ & $1.18^{\mathrm{a}}$ \\
\hline White oak & $13 \pm 1$ & $12^{\mathrm{a}}$ & $15 \pm 1$ & $15^{\mathrm{bc}}$ & $1.38 \pm 0.26$ & $1.25^{\mathrm{a}}$ \\
\hline Sweetgum & $12 \pm 1$ & $11^{\mathrm{a}}$ & $13 \pm 1$ & $12^{\mathrm{bc}}$ & $1.45 \pm 0.18$ & $1.30^{\mathrm{a}}$ \\
\hline Loblolly pine & $\mathrm{n} / \mathrm{a}$ & $\mathrm{n} / \mathrm{a}$ & $18 \pm 2$ & $19^{\mathrm{ac}}$ & $\mathrm{n} / \mathrm{a}$ & $\mathrm{n} / \mathrm{a}$ \\
\hline
\end{tabular}

Letters denote difference among study species based on the Kruskal-Wallis test $(p<0.05)$ 
Fig. 1 The variability of the actual and potential hygroscopicity of the outer and total bark expressed $\mathbf{a}$ in millimeters and b as a percent of the dry mass of outer and total bark. Different letters indicate significant differences in bark properties within bark types (outer bark analyzed separately from total bark) among tree species $(p<0.05)$
Table 2 Statistics of the outer and total bark thickness $(\mathrm{cm})$ and the outer to total bark thickness ratio of particular tree species
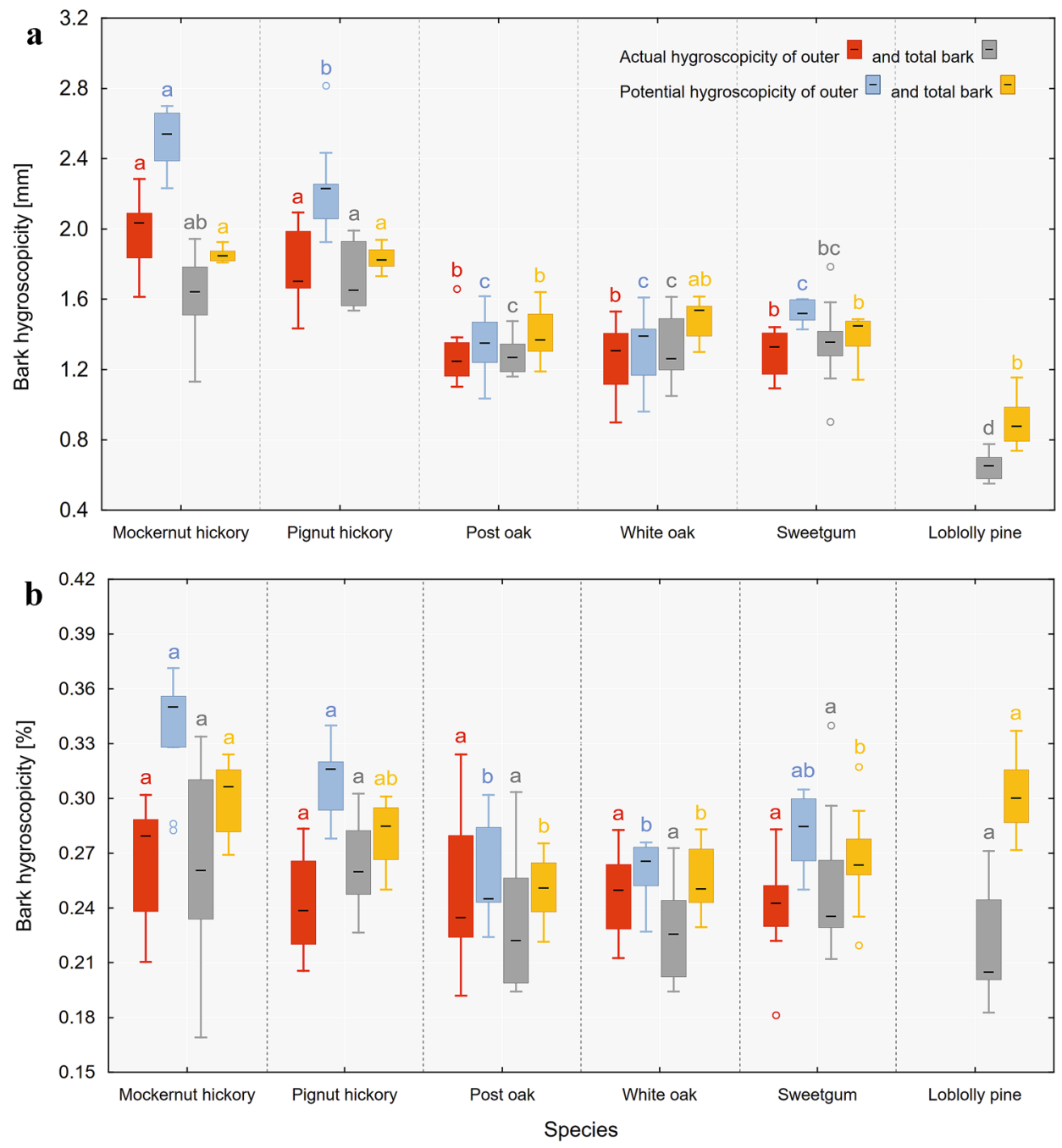

\begin{tabular}{|c|c|c|c|c|c|c|}
\hline \multirow[t]{2}{*}{ Species } & \multicolumn{2}{|c|}{ Outer bark thickness* } & \multicolumn{2}{|c|}{ Total bark thickness $* *$} & \multicolumn{2}{|c|}{$\begin{array}{l}\text { Outer to total bark thick- } \\
\text { ness ratio* }\end{array}$} \\
\hline & Mean \pm Std error & Median & Mean \pm Std error & Median & $\overline{\text { Mean } \pm \text { Std error }}$ & Median \\
\hline Mockernut hickory & $0.56 \pm 0.08^{\mathrm{ab}}$ & 0.51 & $1.49 \pm 0.07$ & $1.54^{\mathrm{a}}$ & $0.37 \pm 0.05^{\mathrm{a}}$ & 0.33 \\
\hline Pignut hickory & $0.57 \pm 0.07^{\mathrm{ab}}$ & 0.55 & $1.38 \pm 0.11$ & $1.39^{\mathrm{a}}$ & $0.43 \pm 0.05^{\mathrm{ab}}$ & 0.45 \\
\hline Post oak & $0.85 \pm 0.09^{\mathrm{bc}}$ & 0.78 & $1.31 \pm 0.13$ & $1.19^{\mathrm{ab}}$ & $0.65 \pm 0.03^{\mathrm{cd}}$ & 0.64 \\
\hline White oak & $0.94 \pm 0.11^{\mathrm{c}}$ & 0.97 & $1.20 \pm 0.09$ & $1.14^{\mathrm{ab}}$ & $0.77 \pm 0.05^{\mathrm{d}}$ & 0.79 \\
\hline Sweetgum & $0.43 \pm 0.05^{\mathrm{a}}$ & 0.43 & $0.72 \pm 0.06$ & $0.70^{\mathrm{b}}$ & $0.58 \pm 0.03^{b c}$ & 0.55 \\
\hline Loblolly pine & $\mathrm{n} / \mathrm{a}$ & $\mathrm{n} / \mathrm{a}$ & $1.47 \pm 0.16$ & $1.48^{\mathrm{a}}$ & $\mathrm{n} / \mathrm{a}$ & $\mathrm{n} / \mathrm{a}$ \\
\hline
\end{tabular}

Letters denote difference in outer, total, or outer:total bark thickness among study species based on Tukey and Kruskal-Wallis tests

*Tukey's test

$* *$ Kruskal-Wallis test $(p<0.05)$

$29.3 \%$ greater bulk density than the other species. For bulk density of total bark, there were less clear trends among genera, but loblolly pine bulk density was $48.7 \%$ lower than the broadleaved species. Bulk density was a strong predictor of hygroscopicity, with stronger correlations among potential hygroscopicity (outer bark: $r^{2}=0.85$, total bark: $r^{2}=0.81$ ) compared to actual hygroscopicity (outer bark: $r^{2}=0.73$, total bark: $r^{2}=0.65$ ) (Fig. 3a). 
Fig. 2 The variability of a specific density of outer and total bark, $\mathbf{b}$ bulk density of outer and total bark, $\mathbf{c}$ total porosity of outer and total bark of individual tree species. Different letters indicate significant differences in bark properties within bark types (outer bark analyzed separately from total bark) among tree species $(p<0.05)$
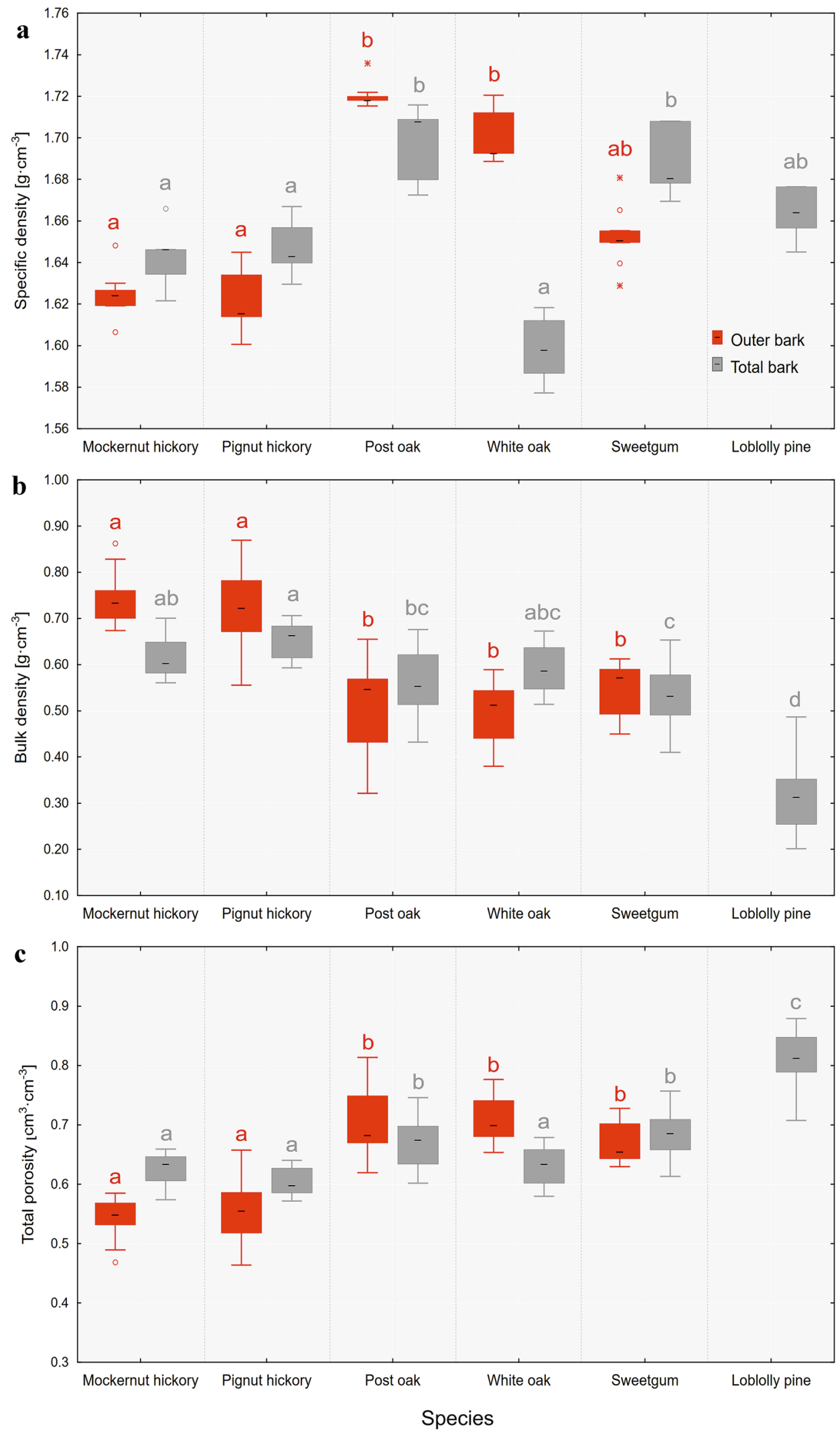
Fig. 3 The correlation between the actual and potential hygroscopicity of the outer and total bark with a bulk density and $\mathbf{b}$ total porosity
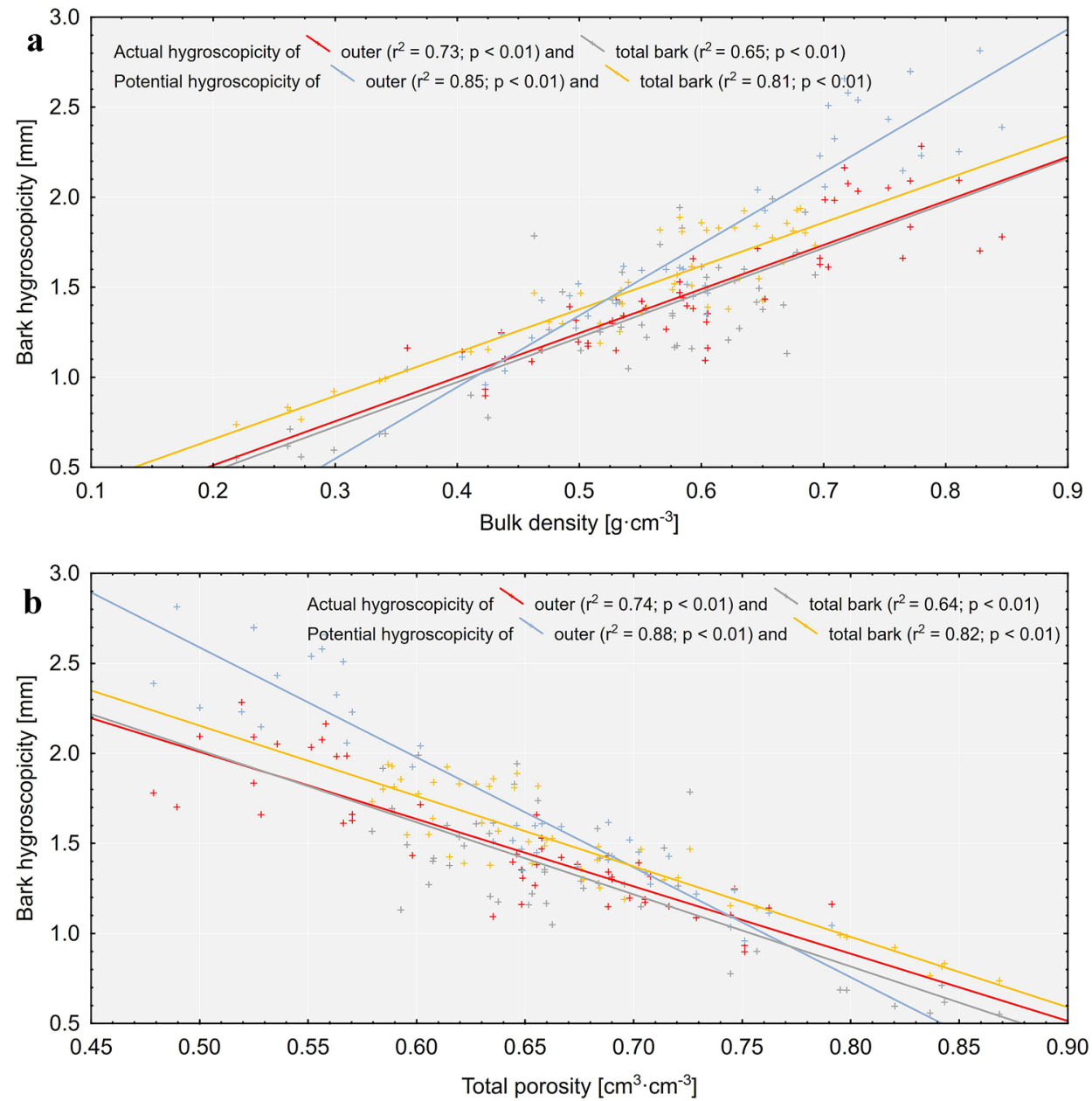

Total porosity of outer bark ranged from 0.48 to $0.79 \mathrm{~cm}^{3} \mathrm{~cm}^{-3}$, while total porosity of total bark ranged from 0.58 to $0.87 \mathrm{~cm}^{3} \mathrm{~cm}^{-3}$ (Fig. 2c). For both outer and total bark, hickories had lower total porosity compared to all other species (except white oak total bark porosity). The highest porosity was observed in loblolly pine total bark $\left(0.82 \pm 0.01 \mathrm{~cm}^{3} \mathrm{~cm}^{-3}\right)$. Porosity was similarly a strong predictor of hygroscopicity, again with stronger correlations among potential hygroscopicity (outer bark: $r^{2}=0.88$, total bark: $r^{2}=0.82$ ) compared to actual hygroscopicity (outer bark: $r^{2}=0.74$, total bark: $\left.r^{2}=0.64\right)$ (Fig. 3b).

\section{Bark water storage capacity}

Total bark water storage capacity of loblolly pine was $22.5 \%$ lower than that of broadleaved species (Fig. 4). Although there were no differences in bark water storage capacity in total bark among broadleaved species, the variability of bark water storage capacity of total bark was less than that in outer bark with a range of $1.68-6.58 \mathrm{~mm}$.

The proportion of bark water storage capacity occupied by actual hygroscopicity ranged from 11.4 to $61.9 \%$ in outer bark and from 17.3 to $41.5 \%$ in total bark (Fig. 5). Post oak generally had less bark water storage capacity occupied by hygroscopicity while hickories had the most.

\section{Discussion}

Among the broadleaved tree species considered in this study, they can be divided into two groups based on the ratio of the thickness of outer bark to total bark: (1) species whose inner bark contributes to the majority of total bark thickness (mockernut hickory, pignut hickory, sweetgum), and (2) species whose outer bark contributes to the majority of total bark thickness (post oak, white oak) (Table 2). The bark thickness ratio for loblolly pine was not considered in this study due to the extremely thin nature of inner bark and the degree of difficulty in complete extraction of the bark sample in the field as well as separation of the tissue types in the laboratory. However, Eberhardt et al. (2009) indicate that the loblolly pine may have up to 5.8 times more outer bark than inner bark, which would place loblolly pine to the second group as well. 
Fig. 4 The variability of the water storage capacity of outer and total bark of individual tree species. Different letters indicate significant differences in bark properties within bark types (outer bark analyzed separately from total bark) among tree species $(p<0.05)$
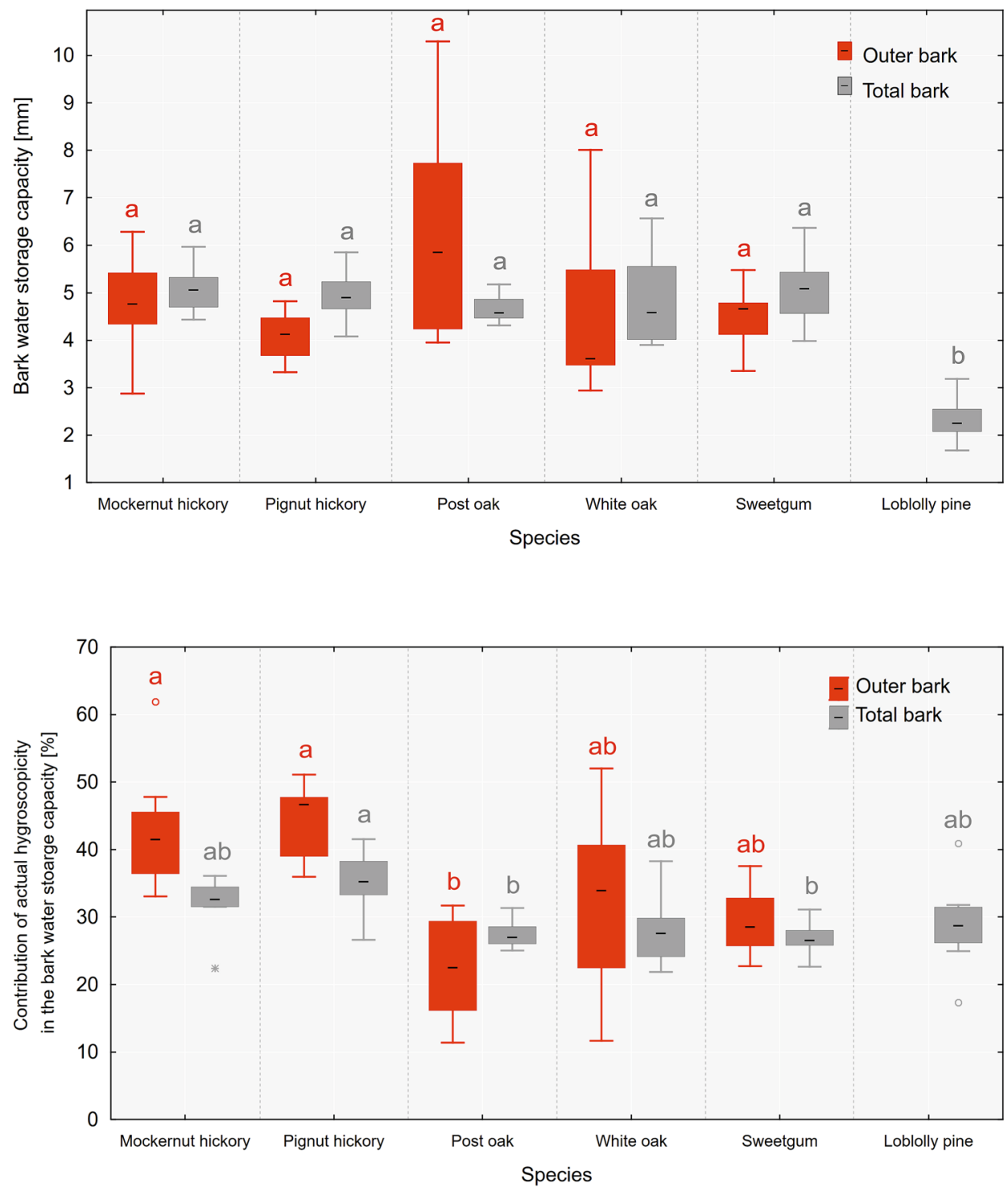

Fig. 5 The contribution of the actual hygroscopicity in the water storage capacity of the outer and total bark. Different letters indicate significant differences in bark properties within bark types (outer bark analyzed separately from total bark) among tree species $(p<0.05)$
Interspecific differences in the ratio of thickness of outer to total bark have a reflection on the physical properties of the bark. Since the bulk density of inner bark is usually lower than the bulk density of outer bark (Meyer et al. 1981), species with a predominant share of inner bark have, in general, lower total bark bulk density and higher total bark porosity in comparison with density and porosity of outer bark (Fig. 2). In turn, species with a predominant share of outer bark have a higher total bark bulk density and lower total bark porosity in comparison with density and porosity of outer bark tissue alone, which was especially evident in white oak bark in this study.

Differences in the physical and structural characteristics of bark were manifest in actual and potential hygroscopicity among tree species but not in the total water storage capacity itself, except for loblolly pine. Due to high porosity and low bulk density, the bark of loblolly pine should theoretically have a high water storage capacity (Fig. 2), the water storage capacity of loblolly pine bark was less than half the water storage capacity of broadleaved tree species (Fig. 4). This may be caused by a hydrophobic surface on the outer bark of pine inhibiting in water absorption to internal structures (Yap et al. 2014), even when immersed in water for extended periods of time. Additionally, pine bark has a more layered, platy structure (Hodges et al. 2012). One possible mechanism could be that a majority of water is likely adhered between the thin inter-layers and not absorbed into internal bark structures, although this mechanism has not yet been investigated.

Interestingly, the lack of significant differences in bark water storage capacity between broadleaved tree species is opposite to other studies, where the interspecific differences were observed (Levia and Herwitz 2005; Valovà and Bieleszovà 2008). However, the 7-day soaking process of 
bark samples with isolated back and side surface employed in this study may not have actually reached the maximum water storage capacity of the bark. Ilek et al. (2017b) found that the time needed to saturate bark is very long, up to 60 days, depending on tree species. The process of soaking until maximum water storage capacity enables an objective comparison among tree species, but it is not representative of real-world conditions. In turn, Valová and Bieleszová (2009) showed interspecific differences in bark water storage capacity after $24-\mathrm{h}$ of bark soaking. The differences found after such a relatively short time of the bark immersion process may result from different properties of bark surface area and hydrophobicity among tree species. Therefore, to clarify the bark water storage capacity, a uniform research methodology is needed.

Our experiments have demonstrated the strong correlation between actual hygroscopicity and bulk density and total porosity of the outer and total bark (Fig. 3). A similar relationship was found by Ilek et al. (2017a) for the total bark of 8 tree species in European temperate forests. When bark samples were exposed to $100 \%$ relative humidity, the time of achievement of the actual hygroscopicity varied among tree species, with species with lower bulk density and higher porosity (e.g., sweetgum) reaching maximum hygroscopicity faster. The relationship of moisture content and density of woody tissues is well documented (Simpson 1993; Glass and Zelinka 2010). The hygroscopic properties of wood are associated both with the large internal surface of wood, as well as wood chemical composition (Okoh and Skaar 1980; Kokociński 2004). Bark with high bulk density and low porosity has a large internal surface and can absorb much more water from the atmosphere than bark with low density and high porosity.

Furthermore, we found that the potential hygroscopicity was generally higher than actual hygroscopicity, both for outer and total bark, which suggests that bark structure might affect the 'access' of bark tissues, which can absorb water from the atmosphere (Fig. 1). The destruction of the bark structure caused an increase in the surface of bark material, and thus an increase in the amount of absorbed water, which is particularly evident in species with highdensity bark such as mockernut hickory and pignut hickory. The actual hygroscopicity exhibited some interspecific variation for both outer and total bark (Fig. 1a), but such differentiation was not observed for the actual hygroscopicity expressed as a percent of the dry mass of bark (Fig. 1b). This suggests that $1 \mathrm{~g}$ of bark with intact structure absorb similar quantities of water, regardless of tree species. However, given the physical properties of bark, the amount of bark material in the volume unit varies between species. For example, $1 \mathrm{~cm}^{3}$ of high-density and low-porosity bark contains more bark material, than $1 \mathrm{~cm}^{3}$ of low-density and high-porosity bark, which can partially explain the interspecies variation in the actual hygroscopicity express in millimeters.

In the case of potential hygroscopicity of the outer and total bark, we found some interspecific differences, both for potential hygroscopicity expressed in millimeters and as a percentage of dry mass (Fig. 1). Taking into account that each ground bark sample was first sifted through a $0.25 \mathrm{~mm}$ sieve and tapped to remove any large air pockets, we can assume that $1 \mathrm{~cm}^{3}$ of each ground bark sample contained the same quantity and surface area of bark material. Therefore, the amount of water absorbed by samples of different species should be similar due to similar surface area and mass. According to Hill et al. (2009), absorption of water vapor by natural fibers from the atmosphere is possible due to the presence of hydroxyl $(\mathrm{OH})$ groups associated with the cell wall macromolecules to which mainly belong cellulose, lignin, hemicellulose, and pectic component. Therefore, the interspecific variation in the potential hygroscopicity may be due to differences in the chemical composition of the bark.

Our research indicates that apart from outer bark, the inner bark can also absorb water vapor from the atmosphere. However, the time needed to reach the maximum hygroscopicity by total bark is on average, 6 days longer than the time needed for outer bark, and in case of high-density bark species such a mockernut hickory and pignut hickory, these times nearly double. The shorter time for water absorption by the outer bark indicates that it is the most active bark layer reacting on changes in atmospheric humidity, and its share in the hygroscopicity of total bark for most of the studied broadleaved tree species exceeds 50\%. As bark absorbs water vapor, it swells (Reifsnyder et al. 1967) increasing the diameter of the trees with a 2-3 h delay (Gall et al. 2002). Although we found that the inner bark can absorb water vapor from the air, our study is limited by the fact that observations were made on dried bark samples and deprived of contact with other living wood tissue of trees. During the life of the trees, the inner bark is physiologically active, and its moisture content can be close to $100 \%$. Moreover, the moisture content in the total bark shows seasonal variation, with a maximum in summer and minimum in winter (Reifsnyder et al. 1967). Therefore, the importance of water absorption by the inner bark is probably greater outside the growing season, in autumn and winter, when the inner bark is less active or inactive.

Collectively, the connections between bark physical characteristics and water relations extend beyond the individual samples of bark evaluated in this study and can have implications to the broader hydrologic cycle. One of these implications could be the control on the distribution of rainfall by forest trees into throughfall and stemflow. For example, when bark becomes saturated with water, either completely or in localized areas, water is diverted from bark absorption to stemflow. Traditionally, the quantity of stemflow produced 
by trees has been evaluated as a function of tree species, bark morphology, tree age, and rainfall characteristics (André et al. 2008; Germer et al. 2010; Van Stan and Levia 2010; Siegert and Levia 2014). In this paper, we demonstrate the role of internal bark structural characteristics on water absorption and retention through hygroscopicity. While our laboratory experiments were conducted under conditions of maximum bark saturation, natural rainfall events are of variable lengths in duration and do not always result in complete bark saturation. As such, our results demonstrate the maximum degree to which differences in bark water absorption and retention vary among species and provide a preliminary evidence of how these processes may be differentiated among species in natural conditions.

Taking into account interspecific differences in relation to outer, inner or total bark structure (Bauer et al. 2010; Rosell 2019) and bark water storage capacity (Valovà and Bieleszovà 2008), the contribution of bark hygroscopicity in bark water storage capacity likely vary among tree species. The actual hygroscopicity of total bark could constitute, on average, $30 \%$ of bark water storage capacity, determined after 7 days of immersion of bark samples in water. Ilek et al. (2017a) found that, depending on the tree species, the value of actual hygroscopicity may constitute $10-30 \%$ of bark water storage capacity. In turn, the hygroscopicity of the outer bark can reach up to $62 \%$ of its total water holding capacity (approximately $34 \%$ on average). This indicates that the hygroscopicity of the outer layer of the bark is an important element of its water properties and should not be neglected. Here, bark hygroscopicity may be especially important in humid climates, where atmospheric vapor is readily available for absorption in bark tissues. Species with higher hygroscopicity like hickory will likely retain higher levels of bark water during non-rainfall conditions, functionally decreasing the capacity of bark to absorb rainwater, compared to oaks. High hygroscopic saturation of bark preceding a rain event may reduce the time to canopy storage, reducing overall interception and causing throughfall and stemflow to initiate more readily. This process may be especially important for bark with high hygroscopicity and low water storage capacity, in which hygroscopicity has a large contribution in total water storage capacity of bark.

Thus, future research on how forests interact with precipitation may benefit from observations of how both the internal and external bark structures interact with water vapor between storms. At the individual tree level, further investigations should consider the variability of hygroscopicity and other bark physical properties along the tree trunk and how the distribution of these properties changes with age (Campellone et al. 2020). In high-diversity mixed-species stands, this knowledge can be used to refine parameterization of stem storage in analytical rainfall interception models where estimates of multi-species are scarce (Linhoss and
Siegert 2016). Additionally, unravelling the direct connections between bark hygroscopicity observed in the laboratory with field observations of stemflow will improve our understanding of the mechanistic processes driving stemflow generation among species and guide our understanding of biogeochemical processes as well (Tucker et al. 2020).

\section{Conclusions}

We evaluated the physical, water, and hygroscopic properties of outer and total bark of six common tree species in the southeastern USA. The results reveal the following:

(1) Species with higher the bulk density and lower the total porosity of bark (of outer or total bark), had higher actual hygroscopicity of bark,

(2) Differences between potential and actual hygroscopicity of outer and total bark indicate that bark structure might affect the 'accessibility' of bark tissues, which can absorb water from the atmosphere,

(3) The time needed to reach the actual hygroscopicity by total bark is about six days longer than the time needed for outer bark. This indicates that outer bark is the most active bark layer reacting to changes in air relative humidity,

(4) Bark hygroscopicity can represent $>60 \%$ of bark water storage capacity. Thus, the ability of bark to absorb water vapor during non-rainfall periods keeps bark tissues in a degree of saturation between rainfall events that may affect bark water holding capacity and stemflow production during rainfall.

Author contributions statement Conceptualization: AI, CS, Sample collection and preparation for analysis: AI, AW, Methodology: AI, CS, AW, Investigation: AI, AW, Analysis and interpretation of data: AI, CS, Resources: AI, CS, Writing —original draft preparation, review and editing: AI, CS, Writing-language review and editing: CS.

Acknowledgements This work was supported by the National Science Centre, Poland: decision no. DEC-2018/02/X/NZ9/03224. This material is a contribution of the Forest and Wildlife Research Center, Mississippi State University and is based upon work that is supported by the National Institute of Food and Agriculture, USA. Department of Agriculture, McIntire-Stennis project under accession numbers MISZ-032100.

\section{Compliance with ethical standards}

Conflict of interest The authors declare that they have no conflict of interest. 
Open Access This article is licensed under a Creative Commons Attribution 4.0 International License, which permits use, sharing, adaptation, distribution and reproduction in any medium or format, as long as you give appropriate credit to the original author(s) and the source, provide a link to the Creative Commons licence, and indicate if changes were made. The images or other third party material in this article are included in the article's Creative Commons licence, unless indicated otherwise in a credit line to the material. If material is not included in the article's Creative Commons licence and your intended use is not permitted by statutory regulation or exceeds the permitted use, you will need to obtain permission directly from the copyright holder. To view a copy of this licence, visit http://creativecommons.org/licenses/by/4.0/.

\section{References}

André F, Jonard M, Ponette Q (2008) Influence of species and rain event characteristics on stemflow volume in a temperate mixed oak-beech stand. Hydrol Process 22:4455-4466

Arguez A, Durre I, Applequist S, Squires M, Vose R, Yin X, Bilotta R (2010) NOAA's US climate normals (1981-2010). National Centers for Environmental Information, Asheville, NC, USA

Bauer G, Speck T, Blömer J, Bertling J, Speck O (2010) Insulation capability of the bark of trees with different fire adaptation. J Mater Sci 45:5950-5959

Biggs AR (1992). Anatomical and physiological responses of bark tissues to mechanical injury. In: Blanchette et al (eds) Defense mechanisms of woody plants against fungi. Springer, Heidelberg, pp 13-40

Bryant ML, Bhat S, Jacobs JM (2005) Measurements and modeling of throughfall variability for five forest communities in the southeastern US. J Hydrol 312(1-4):95-108

Campellone SV, Levia DF, Montalto FA (2020) Differences in submillimeter surface morphology and canopy interception storage capacities of Gleditsia triacanthos L. (honey locust) in relation to canopy phenophase and position. Ecohydrology. https://doi. org/10.1002/eco.2192

Carlyle-Moses DE, Gash JH (2011) Rainfall interception loss by forest canopies. Forest hydrology and biogeochemistry. Springer, Dordrecht, pp 407-423

Dossa GGO, Schaefer D, Zhang JL, Tao JP, Cao KF, Corlett RT, Cunningham AB, Xu JC, Cornelissen JHC, Harrison RD (2018) The cover uncovered: bark control over wood decomposition. J Ecol 106:2147-2160

Eberhardt TL (2012) Longleaf pine inner bark and outer bark thicknesses: measurement and relevance. South J Appl For 37(3): $177-180$

Eberhardt TL (2015) Thickness and roughness measurements for air-dried longleaf pine bark. In: Holley AG, Connor KF, and Haywood JD Proceedings of the 17th Biennial Southern Silvicultural Research Conference, e-Gen. Tech. Rep. No. 203. USDA Forest Service, Southern Research Station, Asheville, NC, pp 374-379

Eberhardt TL, Reed KG, So C-L (2009) Partitioning of pine bark components to obtain a value-added product for plywood manufacture. In: Hse C-Y, Jiang Z, Kuo ML (eds) Advanced biomass science and technology for bio-based products. Chinese Academy of Forestry, Beijing, pp 302-309

Everhart SE, Ely JS, Keller HW (2009) Evaluation of tree canopy epiphytes and bark characteristics associated with the presence of corticolous myxomycetes. Botany 87:509-517

Feng S, Cheng S, Yuan Z, Leitch M, Xu Ch (2013) Valoriation of bark for chemicals and materials: a review. Renew Sustain Energy Rev 26:560-578
Gall R, Landolt W, Schleppi P, Michellod V, Bucher JB (2002) Water content and bark thickness of Norway spruce (Picea abies) stems: phloem water capacitance and xylem sap flow. Tree Physiol 22:613-623

Germer S, Werther L, Elsenbeer H (2010) Have we underestimated stemflow? Lessons from an open tropical rainforest. J Hydrol 395:169-179

Glass SV, Zelinka SL (2010) Moisture relations and physical properties of wood. In: Ross (ed) Wood handbook: wood as an engineering material. RJ GTR-190. U.S. Department of Agriculture, Forest Service, Forest Products Laboratory, Madison, WI, pp 4.1-4.19

Hargis H, Gotsch SG, Porada P, Moore GW, Ferguson B, Van Stan JT (2019) Arboreal epiphytes in the soil-atmosphere interface: How often are the biggest "buckets" in the canopy empty? Geosciences $9(8): 342$

Herwitz SR (1985) Interception storage capacities of tropical rainforest canopy trees. J Hydrol 77:237-252

Herzog KM, Häsler R, Thum R (1995) Diurnal changes in the radius of a subalpine Norway spruce stem: their relation to the sap flow and their use to estimate transpiration. Trees 10(2):94-101

Hill CA, Norton A, Newman G (2009) The water vapor sorption behavior of natural fibers. J Appl Polym Sci 112(3):1524-1537

Hodges JD, Evans DL, Garnett LW (2012) Mississippi trees, 2nd edn. Mississippi Forestry Commission, US, p 369

Ilek A, Kucza J, Morkisz K (2017a) Hygroscopicity of the bark of selected forest tree species. iForest 10:220-226

Ilek A, Kucza J, Morkisz K (2017b) Hydrological properties of bark of selected forest tree species. Part 2: interspecific variability of bark water storage capacity. Forestry 59(2):110-122

Kokociński W (2004) Drewno: pomiar właściwości fizycznych i mechanicznych [Timber: measurements of physical and mechanical properties]. Wydawnictwo-Drukarnia PRODRUK Poznań: 53-55 (in Polish)

Krogell J, Holmbom B, Pranovich A, Hemming J, Willför S (2012) Extraction and chemical characterization of Norway spruce inner and outer bark. Nord Pulp Pap Res J 27(1):6-17

Levia DF, Herwitz SR (2005) Interspecific variation of bark water storage capacity of Tyree deciduous tree species in relation to stemflow yield and solute flux to forest soils. CATENA 64:117-137

Limpert K, Siegert C (2019) interspecific differences in canopy-derived water, carbon, and nitrogen in Upland Oak-Hickory forest. Forests 10:1121. https://doi.org/10.3390/f10121121

Linhoss AC, Siegert CM (2016) A comparison of five forest interception models using global sensitivity and uncertainty analysis. J Hydrol 538:109-116. https://doi.org/10.1016/j.jhydr ol.2016.04.011

Liu S (1998) Estimation of rainfall storage capacity in the canopies of cypress wetlands and slash pine uplands in North-Central Florida. J Hydrol 207(1-2):32-41

Llorens P, Gallart F (2000) A simplified method for forest water storage capacity measurement. J Hydrol 240(1-2):131-144

Llorens P, Poch R, Latron J, Gallart F (1997) Rainfall interception by a Pinus sylvestris forest patch overgrown in a Mediterranean mountainous abandoned area I. Monitoring design and results down to the event scale. J Hydrol 199(3-4):331-345

Martin RE, Crist JB (2007) Elements of bark structure and terminology. Wood Fiber Sci 2(3):269-279

Meyer RW, Kellogg RM, Warren WG (1981) Relative density, equilibrium moisture content, and dimensional stability of western hemlock bark. Wood Fiber 13(2):86-96

Nicolai V (1986) The bark of trees: and fauna thermal properties, microclimate. Oecologia 69:148-160

Oberhuber W, Sehrt M, Kitz F (2020) Hygroscopic properties of thin dead outer bark layers strongly influence stem diameter variations 
on short and long time scales in Scots pine (Pinus sylvestris L.). Agric For Meteorol 290:108026

Okoh KIA, Skaar Ch (1980) Moisture sorption isotherms of the wood and inner bark of ten southern U.S. hardwoods. Wood Fiber 12(2):98-111

Pausas JG (2015) Bark thickness and fire regime. Funct Ecol 29:315-327

Pfautsch S, Renard J, Tjoelker MG, Salih A (2015) Phloem as capacitor: Radial transfer of water into xylem of tree stems occurs via symplastic transport in ray parenchyma. Plant Physiol 167(3):963-971

Pinard MA, Huffman J (1997) Fire resistance and bark properties of trees in a seasonally dry forest in eastern Bolivia. J Trop Ecol 13(5):727-740

Reifsnyder WE, Harrington LP, Spalt KW (1967) Thermophysical properties of bark of shortleaf, longleaf, and red pine. Yale University Forestry Bulletin Number 70. Yale University School of Forestry, New Haven, Connecticut

Romero C (2014) Bark: structure and functional ecology. In: Cunningham AB, Campbell BM, Luckert MK (eds) Bark: use, management, and commerce in Africa. The New York Botanical Garden Press, Bronx, pp 5-25

Rosell JA (2016) Bark thickness across the angiosperms: more than just fire. New Phytol 211:90-102

Rosell JA (2019) Bark in woody plants: understanding the diversity of a multifunctional structure. Integr Comp Biol 59(3):535-547

Rosell JA, Olson ME, Anfodillo T, Martinez-Mendez N (2017) Exploring the bark thickness-stem diameter relationship: clues from lianas, successive cambia, monocots and gymnosperms. New Phytol 215:569-581

Roth BE, Slatton KC, Cohen MJ (2007) On the potential for highresolution lidar to improve rainfall interception estimates in forest ecosystems. Front Ecol Environ 5(8):421-428

Schultz RP (1997) Loblolly pine: the ecology and culture of loblolly pine (Pinus taeda L.). Agriculture Handbook 713. Department of Agriculture, Forest Service, Washington, DC, USA

Siegert CM, Levia DF (2014) Seasonal and meteorological effects on differential stemflow funneling ratios for two deciduous tree species. J Hydrol 519:446-454
Simpson WT (1993) Specific gravity, moisture content, and density relationship for wood. General Technical Report FPL-GTR-76. U.S. Department of Agriculture, Forest Service, Forest Products Laboratory, Madison, Wisconsin, USA

Spalt KW, Reifsnyder WE (1962) Bark characteristics and fire resistance: a literature survey. United States Department of Agriculture Forest Service Occasional Paper S-193, Southern Research Station, New Orleans, Louisiana, USA

Staver AC, Brando PM, Barlow J, Morton DC, Paine CET, Malhi Y, Murakami AA, Pasquel A (2020) Thinner bark increases sensitivity of wetter Amazonian tropical forests to fire. Ecol Lett 23(1):99-106

Tucker A, Levia DF, Katul GG et al (2020) A network model for stemflow solute transport. Appl Math Model 88:266-282. https://doi. org/10.1016/J.APM.2020.06.047

Valovà M, Bieleszovà S (2008) Interspecific variations of bark's water storage capacity of chosen types of trees and the dependence on occurrence of epiphytic mosses. GeoSci Eng LIV 4:45-51

Van Stan JT, Levia DF (2010) Inter- and intraspecific variation of stemflow production from Fagus grandifolia Ehrh. (American beech) and Liriodendron tulipifera L. (yellow poplar) in relation to bark microrelief in the eastern United States. Ecohydrology 3:11-19

Van Stan JT, Stubbins A, Bittar T, Reichard JS, Wright KA, Jenkins RB (2015) Tillandsia usneoides (L.) L. (Spanish moss) water storage and leachate characteristics from two maritime oak forest settings. Ecohydrology 8(6):988-1004

Yap TC, Jackson BE, Fonteno WC (2014) Water retention of processed pine wood and pine bark and their particle size fractions. In: Proceedings of the 2014 annual meeting of the international plant propagators society

Publisher's Note Springer Nature remains neutral with regard to jurisdictional claims in published maps and institutional affiliations. 